\title{
Pemilihan Presiden dan Wakil Presiden Secara Langsung
}

\author{
Sunyoto Usman
}

Direct presidential election system is not always a guarantee to choose that the choosen leader is always the best to govern this nation. In democration process we find some factors that not always rational and objective to choose the leader. It can depend on subyektif emtional factors which liebehind the primordialisme and also, we can't neglect the factor of personal benefit orientation as a result of mony politics. The election system must encourage that only candidate who have morality, integrity and capabilty and support from the more people that will emerge to bring the good of the society and nations.

\section{$\mathrm{T}$} ekad bangsa ini menyelenggarakan pemilihan umum yang jujur dan adil. mencuat ke permukaan kuat sekali. Kuatnya tekad itu antara lain terefleksi pada kesepakatan politik menyelenggarakan pemilihan presiden dan wakil presiden secara langsung dalam pemilihan umum yang akan datang. Melalui sistim ini diyakini bahwa pemilihan presiden dan wakil presiden secara langsung dapat menghasilkan pemimpin yang bukan hanya berkualitas tetapi juga dekat dengan rakyat pemilih. Melalui sistim ini pula rakyat diharapkan tidak lagi terus menerus dirugikan oleh pelbagai bentuk persengkokolan dan permainan politik yang tidak terpuji yang dilakukan para wakil rakyat yang ada di parlemen. Melalui sistım itu, proses rekruitmen presiden dan wakil presiden menjadi lebih transparan, kompetisi lebih fair, dan partisipasi rakyat pemilihpun menjadi lebih besar. Seperti telah banyak dilontarkan pengamat politik, bahwa transparansi, kompetisi dan partisipasi masih menjadi barang langka di negara ini. Karena itu tidak mengherankan apabila masih banyak diketemukan politisi, pejabat atau intelektual yang ucapannya berbuih demokrasi, tetapi tindakannya tidak demokratis.

\section{Pengalaman Pertama}

Untuk pertama kalinya, presiden dan wakil presiden dipilih dalam satu paket dan dipilih langsung. Apabila masa-masa sebelumnya calon wakil presiden hanya diposisikan sebagai pendamping calon presiden, dan lazimnya dipilih di antara orang yang memang dikehendaki oleh calon presiden, kini calon wakil presiden adalah figur alternatifyang bisa menentukan peroleh dukungan calon presiden: Karena itu menjadi mudah dimengerti apabila partai politik terlihat hati-hati sekali menentukan pasangan calon presiden dan calon wakil presiden. Para politisi sadar betul bahwa dengan sistim multi partai seperti sekarang sangat sulit menghantarkan calon presiden dari partainya akan memperoleh suara 
mayoritas mutlak, sehingga dibutuhkan koalisi dengan partai-partai lain. Namun demikian, mereka juga kelihatan tidak gegabah menentukan pasangan calon presiden dan wakil presiden yang kelak akan didukung. Karena kesalahan dalam menentukan pasangan itu bisa berakibat fatal bagi kehidupan partainya.

Pertanyaannya kemudian adalah benarkah sistim pemilihan presiden dan wakil presiden semacam itu akan melahirkan pemimpin yang berkualitas dan dekat dengan rakyat pemilih? Tidak mudah menjawabnya, karena proses memilih figur pemimpin sebenarnya dipengaruhi oleh pelbagai macam faktor yang tidak selamanya bersifat obyektif-rasional, atau di atas pertimbangan yang dilandasi nalar yang jelas. Proses memilih figur pemimpin bisa dipengaruhi oleh faktor yang bersifat subyektif-emosional produk dari bekerjanya ikatan primodial yang bersumber pada otoritas tradisional, serta di atas pertimbangan memperoleh keuntungan pribadi (materi) berkat bekerjanya mesin money politics. Oleh karena itu, seperti pengalaman yang diperlihatkan oleh banyak negara, sistim pemilihan presiden dan wakil presiden boleh jadi memang mendekatkan pemimpin dengan rakyat pemilih, tetapi tidak selamanya mampu melahirkan pemimpin yang berkualitas, atau benar-benar memiliki kemampuan iandal mengatasi krisis ekonomi maupun politik.

\section{Faktor-Faktor yang Mempengaruhi Pemilih}

Dalam beberapa bulan terakhir ini telah dilakukan sejumlah polling baik oleh media massa, lembaga swadaya masyarakat, maupun oleh perguruan tinggi mengenai siapa di antara tokoh partai yang layak menjadi presiden republik ini. Hasil yang mereka peroleh ternyata bervariasi. Seorang tokoh yang memperoleh ranking tertinggi dari polling yang dilakukan oleh lembaga tertentu, ternyata hanya berada di urutan tengah, atau bahkan berada di papan bawah, "dari polling yang dilakukan oleh lembaga tertentu lainnya, dan demikian pula sebaliknya. Boleh jadi metode polling yang mereka terapkan berbeda, tetapi satu hal yang telah lama menandai kehidupan politik bangsa ini adalah tidak menentu arahnya. Seorang tokoh politik yang semula dimaki karena dianggap tidak cerdas dalam berpolitik, bisa berubah dielu-elukan bak pahlawan yang baru memenangkan peperangan. Seorang tokoh politik yang semula dimaki karena dituduh sebagai biang korupsi, bisa berubah dipuji dan dijagokan sebagai figur alternatif yang diharapkan memimpin bangsa ini. Itulah sebabnya. bukan hanya tidak mudah membuat analisis tentang situasi yang bakal terjadi dalam proses pemilihan presiden dan wakil presiden secara langsung nanti, tetapi juga tidak mudah memprediksi bagaimana karakteristik kepemimpinan yang kelak lahir dari proses semacam itu.

Banyak studi telah memperlihatkan bahwa tindakan memilih, termasuk memilih calon presiden dan wakil presiden, bisa dipengaruhi oleh banyak faktor yang melekat dalam status sosial-ekonomi, kultur maupun struktur sosial. ${ }^{1}$ Karena itu mereka yang tergolong dalam status sosial ekonomi atas memiliki tindakan memilih:yang berbeda dengan mereka yang tergolong dalam status sosial ekonomi bawah atau menengah. Mereka yang berasal dari kalangan tradisional-agraris memiliki tindakan memilih

1. Oliver H. Woshinsky, Culture and Politics, Prentice Hall, Englewood Cliffs, New Jersey, 1995, pp 129-130 
yang berlainan dengan mereka yang berasal dari kalangan modern-industrial. Demikian pula mereka yang berasal dari kalangan masyarakat yang ditandai oleh struktur kekuasaan yang monolitik, atau dalam bingkai otoritas tradisional, mempunyai tindakan. memilih yang berlainan dengan mereka yang berasal dari kalangan masyarakat yang ditandai oleh struktur kekuasaan yang pluralis, dtau dalam bingkai otoritas rasional.

Apabila pandangan semacam itu dipergunakan sebagai referensi, maka proses pemilihan presiden dan wakil presiden dalam pemilu nanti diperkirakan diwarnai oleh tindakan memilih yang bervariasi. Tindakan memilih mereka yang berasal dari kalangan masyarakat urban, atau yang mayoritas terdidik, diperkirakan sudah dalam bingkai pertimbangan obyektifrasional. Sebagian besar kalangan ini akan memilih calon presiden dan calon wakil presiden yang memiliki program-program yang jelas, atau yang diperkirakan dapat meningkatkan kesejahteraan masyarakat seperti: mengentaskan kemiskinan, menciptakan lapangan kerja dan menekan angka pengangguran, meningkatkan pendidikan dan sejenisnya. Kalangan ini memiliki kemampuan melakukan evaluasi, karena diperkirakan lebih menekankan pada apa yang bisa dikerjakan oleh calon presiden dan wakil presiden itu, bukan pada dari rahim siapa dilahirkan. Tindakan memilih semacam itu diperkirakan akan dominan di Jakarta dan di ibukota propinsi.

Simentara itu tindakan memilih mereka yang berasal dari kalangan masyarakat pedesaan, atau yang mayoritas berpendidikan rendah, masih didominasi oleh pertimbangan subyektif-emosional. Kalangan ini kurang memiliki kemampuan melakukan evaluasi, karena itu kurang begitu memperhatikan program-program yang ditawarkan oleh calon presiden dan calon wakil presiden yang kelak berkompetisi. Bagi mereka program-program yang ditawarkan tersebut tidak lebih kewajiban yang harus dipenuhi sesuai dengan ketentuan yang disepakati. Karena .itu tidak dapat dijadikan sebagai ukuran dalam menentukan tindakan memilih. Basis yang mereka pergunakan untuk menakar kualitas atau kapabilitas calon presiden da ir wakil presiden berdasarkan ukuran-ukuran subyektif-yang mereka kembangkan berdasarkan logikanya sendiri, yang bisa berbeda dengan ukuran-ukuran normatif yang lazim dipergunakan untuk memilih calon presiden dan wakil presiden seperti spirit, integritas serta kapasitas.

Pemilihan umum yang akan datang diperkirakan masih kental diwarnai oleh primodialisme, terutama dalam bingkai ikatan agama dan etnis. Kalangan Islam tradisional (berbasis pesantren) akan mempunyai tindakan memilih yang berbeda dengan kalangan Islam perkotaan (berbasis kampus dan jamaah pengajian). Kecenderungan tindakan mimilih yang tumbuh dan berkembang di kalangan mereka berbeda pula dengan kelompok nasionalis (terutama yang tergolong abangan) dan non-muslim. Kemudian, kalangan etnis tertentu juga memiliki tindakan memilih yang berbeda dengan kalangan etnis tertentu lainnya. Etnis yang berbeda tersebut boleh jadi memiliki kepercayaan yang sama, jenis pekerjaan yang kurang lebih sama, atau berada dalam lingkungan masyarakat dengan kondisi geografi dan sosial ekonomi yang kurang lebih sama, tetapi tindakan memilih yang berkembang di kalangan mereka bisa berbeda, bahkan mungkin bertolak belakang sekali. Bagi mereka, tindakan memilih tidaklah digerakkan oleh kemauan berpartisipasi dengan menggunakan hak 
politiknya, tetapi lebih karena memenuhi kewajiban yang diperintahkan oleh komunitas agama atau etnis tempat berafiliasinya. Peran tokoh-tokoh agama dan pemuka-pemuka adat menjadi penting sekali dalam menggalang proses menggalang dukungan rakyat.

Pemilihan umum yang akan datang diperkirakan juga masih kental diwarnai oleh bekerjanya tipe kekuasaan yang dalam percaturan politik lazim disebut otoritas tradisional. ${ }^{2}$ Otoritas tradisional ditandai oleh interaksi dengan karakteristik sebagai berikut. Seorang yang mempunyai pengaruh ( गisa tokoh agama, pemuka adat) menyampaikan pesan (message) kepada pengikutnya, dan pengikut itu mengadopsi pesan tersebut sesuai dengan basis tindakannya dengan penuh kepatuhan (tanpa evaluasi jernih. Kepatuhan itu terutama dilandasi oleh proses sosial yang panjang terkait dengan utang-budi, balasbudi, serta perasaan lain yang saling menguntungkan. Otoritas tradisional adalah 'the exercise of personalistic power' yang lahir dari akumulasi peran tokoh-tokoh agama atau pemuka-pemuka adat) dalam kapasitasnya sebagai pengayom, pelindung, pendidik masyarakat, serta status superior lainnya yang dibangun melalui hubungan yang menciptakan ketergantungan para pengikutnya. Dalam hubungan bercirikan otoritas tradisional itu kedudukan tokoh yang berpengaruh bukan hanya relatif aman dari pelbagai bentuk perubahan yang terjadi dalam masyarakat tetapi juga sangat strategis untuk memobilisasi dukungan. Seorang tokoh tidak pernah salah di persalahkan, karena itu para pengikut akan rela berkorban apa saja demi keberadaan dan kewibawaan tokoh itu. Jargon 'pejah gesang nderek bapak' (hidup mati ikut bapak) adalah bagian dari bekerjanya otoritas tradisional ini dalam masyarakat.

Pertanyaan selanjutnya adalah karakteristik presiden dan wakil presiden seperti apa kelak yang akan terpilih memimpin bangsa ini? Apabila nanti kalangan pemilih yang tergolong obyektif-rasional dominan mempengaruhi proses pemilihan umum, dan pikiran-pikiran cerdas mereka menjadi referensi rakyat ketika hendak menentukan pilihannya, maka boleh jadi kita akan memiliki presiden dan wakil presiden yang populer sekaligus cerdas, dalam arti memiliki kemauan, kemampuan dan ketahuan yang memadai memimpin bangsa ini. Sebaliknya, apabila yang dominan justru kalangan pemilih yang tergolong subyektif-emosional, atau yang tindakan memilihnya lebih dipengaruhi oleh ikatan-ikatan primodial (agama, etnis, daerah) dan dalam bingkai otoritas tradisional, maka kita tidak bisa berharap banyak memiliki presiden dan wakil presiden yang benar-benar capable. Dalam konteks ini, boleh jadi presiden dan wakil presiden itu populer karena memperoleh dukungan dari banyak lapisan masyarakat, tetapi belum tentu capable.

Jaminan Memperoleh Pemimpin yang Kapabel

Model pemilihan presiden secara langsung (populer votes) memiliki dua macam sistim yaitu simple majority dan plurality system. Dalam sistim simple majority pasangan calon presiden dan wakil presiden yang memperoleh suara 'setengah plus

2. Karl D.Jackson dan Johannes Moeliono, 'Participation in Rebellion: The Da'rul Islam in West Java', dalam R. William Liddle, Political Participation in Modem Indonesia, Monograph Series No. 19, 'Yale University Southeast Asia Studies, 1973, pp 17-18 
satu' ditetapkan' sebagai pasangan terpilih. Jadi andaikata jumlah pemilih sebanyak 125 juta, maka siapa yang memperoleh dukungan 62,5 juta plus satu yang ditetapkan sebagai pemenang. Sedangkan dalam plurality system, calon pasangan presiden dan wakil presiden yang memperoleh suara tertinggi yang dinyatakan sebagai pemenang (tidak harus mencapai 62,5 juta). Pemilihan umum yalıg akan datang menganut sistim simple majority. Pemilihan presiden dan wakil presiden dirancang dalam dua putaran. Apabila pada putaran pertama sudah ada pasangan yang memperoleh dukungan setengah jumlah pemilih plus satu, maka putaran kedua tidak lagi dibutuhkan.

Banyak orang percaya bahwa pemilihan presiden dan wakil presiden secara langsung bukan hanya akan menghasilkan pemimpin berkualitas, dekat dengan rakyat pemilih, tetapi juga lebih bersih dan terhindar dari money politics. Argumentasinya senderhana, dengan sistim pemilihan semacam itu rasanya hampir tidak mungkin membagi-bagikan uang kepada puluhan juta pemilih. Andaikata setiap pemilih disogok Rp 1 juta, maka dana yang dikeluarkan sedikitnya $R p 6,25$ trilyun. Partai apa di antara 24 partai yang kini berlaga sanggup menyediakan dana sebesar itu? Andaikata dana itu dapat disediakan, bagaimana pula cara membaginya? Apakah dengan masa jabatan presiden dan wakil presiden selama 5 tahun dapat menghasilkan pendapatan sebesar itu? Karena itu mustahil money politics bisa efektif untuk memenangkan kompetisi merebut kursi presiden dan wakil presiden dalam pemilihan umum yang akan datang.

Argumentasi tersebutcukup nalar, tetapi sejumlah pengamat yakin bahwa pemilihan presiden dan wakil presiden dalam pemilihan umum yang akan datang masih akan diwarnai money politics. Konon partai-partai yang kini berkompetisi tidak sedikit yang memilik dana dalam jumlah besar, dan lebih dari cukup untuk menyogok pemilih andaikata mereka mau. Strateginya mungkin. tidak langsung memberikan uang kepada pemilih, tetapi melalui jaringan sel-sel partai yang telah dibangun. Sel-sel partai berfungsi sebagai semacam broker, makelar yang menjembatani kemauan para pemilih dan kemampuan botoh. Dalam ıal-hal tertentu, sel-sel tersebut juga bisa. menjadi bagian penting dari kegiatan vote getters dengan melakukan intimidasi kepada para pemilih. Dalam konteks ini, para pemilih menjadi dalam posisi terjepit di antara sel-sel dari berbagai macam partai. Mereka tidak ditempatkan sebagai subyek yang dipinang dengan berbagai macam program yang menghadirkan kesejahteraan rakyat, tetapi sebagai obyek yang hampir tidak memiliki posisi tawar politik.

Apabila mekanisme semacam itu yang berjalan, maka kita kelak boleh jadi akan memiliki presiden dan wakil presiden yang populer tetapi tidak bermoral. Mereka adalah pemimpin yang mengabdi pada kemauan preman politik, dan bukan mustahil selama memangku jabatan akan melakukan pelbagai bentuk pemerasan mencari pulihan dana yang dahulu pernah dipergunakan untuk menggalang dukungan rakyat. Konupsi dan pelbagai bentuk persengkokolan akan semakin merajalela, agenda reformasi menjadi semakin sukar diwujudkan, dan rakyat menjadi semakin sengsara. Apabila hal demikian sampai terjadi, maka pemilihan presiden dan wakil presiden bukanlah instrumen untuk memecahkan masalah, bukan pula sebagai mekanisme untuk meredam kemungkinan unfair competition, tetapi justru bagian dari masalah itu sendiri. Iklim politik semakin carut-marut, dan kedaulatan dan kemandirian semakin jauh letaknya. 
Dalam literatur sosiologi, pemimpin lazim dipilahkan ke dalam tiga kategori: visible leader, concealed leader dan symbolic leader. Seorang dinyatakan sebagai visible leader apabila mempunyai banyak pengikut (memperoleh dukungan luas) sekaligus diperhitungkan oleh pemimpin-pemimpin lain. Seorang dinyatakan sebagai concealed leader apabila kepemimpinannya diperhitungan oleh pemimpin-pemimpin lain, meskipun pengikutnya tidak terlalu banyak. Kemudian, seseorang dikategorikan sebagai symbolic leader apabila mempunyai banyak pengikut tetapi kurang diperhitungkan oleh pemimpin-pemimpin lain.

Pertanyaan selanjutnya adalah apa karakteristik presiden dan wakil presiden hasil pemilihan umum yang akan datang? Alternatif jawaban pertanyaan ini sangat tergantung pada bagaimana bentuk partisipasi politik yang kelak berjalan. Apabila presiden dan wakil presiden nanti berasal dari partai besar dan tampil ke permukaan melalui koalisi antar kekuatan politik atas dasar platform politik yang jelas, maka mereka tergolong kategori visible leaders. Apabila partisipasi politik dalam pemilihan presiden dan wakil presiden secara langsung itu digerakkan oleh persengkokolan antar elite-elite politik, maka mungkin kita akan memiliki pempimpin dalam kategori concealed leader, dalam arti memperoleh dukungan pemimpinpemimpin politik tetapi sesungguhnya tidak memiliki banyak pendukung. Kemudian, apabila presiden dan wakil presiden nanti berasal dari partai besar, dan dukungan politik digerakan dengan cera-cara mobilisasi melalui primodialisme, hubungan patron-client, otoritas tradisional atau money politics, maka kita bolehjadi akan memiliki presiden dan wakil presiden dalam kategori symbolic leaders, mempunyai banyak pengikut tetapi sesungguhnya tidak diperhitungkan oleh elite-elite politik lain. Kendatipun presiden dan wakil presiden semacam ini dielu-elukan massa, namun posisinya di parlemen mudah digoyahkan oleh perubahan kepentingan politik.

\section{Daftar Pustaka .}

Woshinsky, Oliver $H, 1995$, Culture and Politics, New Jersey:Prentice Hall, Englewood Cliffs.

Liddle,R. William, 1973, Political Participation in Modem Indonesia, Monograph Series No. 19, Yale University Southeast Asia Studies.

\section{$\square \square \square$}

